DIMENSI, VOL. 7, NO. $1: 100-120$

MARET 2018

ISSN: 2085-9996

\title{
PENGARUH KEPUASAN KERJA DAN KOMITMEN ORGANISASIONAL TERHADAP KINERJA KARYAWAN PT. PHILIPS BATAM
}

\author{
EFFECT OF WORK SATISFACTION AND ORGANIZATIONAL COMMITMENTS ON \\ EMPLOYEE PERFORMANCE PT. PHILIPS BATAM
}

\author{
Endik Sunaryo ${ }^{1}$, Herni Widiyah Nasrul $^{2}$ \\ Program Studi Magister Manajemen Program Pascasarjana Universitas Riau Kepulauan \\ endik@yahoo.com
}

\begin{abstract}
Abstrak
Suatu organisasi baik perusahaan maupun agensi dalam kegiatannya tentu membutuhkan sumber daya manusia yang menunjang upaya pencapaian tujuan yang telah ditetapkan suatu organisasi atau perusahaan. Sumber daya manusia berperan sangat penting, karena faktor manusia menentukan kelangsungan hidup sebuah perusahaan. Tak satu pun dari perusahaan yang tidak melibatkan manusia dan mampu mewujudkan tujuannya. Karena itu tugas Manajer Personalia harus bisa menyesuaikan antara keinginan karyawan dengan tujuan perusahaan. Tujuan dari penelitian ini adalah untuk menguji dan menganalisis pengaruh kepuasan kerja dan komitmen organisasional terhadap kinerja karyawan PT. Philips Batam. Metode penelitian ini adalah metode deskriptif kuantitatif atau bentuk angka yang menjelaskan dan mengolah data yang dikumpulkan dengan kuesioner. Pengambilan sampel sampling mekanis dengan metode simple random sampling, dengan survei melalui kuesioner. Selanjutnya, data yang telah dikumpulkan dalam penelitian ini dianalisis dengan regresi linier berganda dan diolah dengan menggunakan SPSS 21. Hasil uji t, sebagian diketahui bahwa untuk variabel bebas adalah kepuasan kerja (X1) berpengaruh positif dan signifikan terhadap kinerja karyawan. Dan komitmen organisasional (X2) berpengaruh positif dan signifikan terhadap kinerja karyawan. Dari hasil uji F menunjukkan variabel kepuasan kerja (X1) dan komitmen organisasi (X2) secara simultan berpengaruh signifikan terhadap variabel kinerja pegawai.
\end{abstract}

\section{Kata kunci: Kepuasan Kerja, Komitmen Organisasi dan Kinerja Karyawan}

\begin{abstract}
An organization both companies and agencies in their activities is certainly requires human resources that support efforts in achieving the stated goals of an organization or a company. Human resources plays a very important, because the human factor determining the viability of a company. None of the companies that did not involve human beings and be able to realize its objectives. Because it is the duty of Personnel Manager must be able to adjust between the desire of employees with the goals of the company. The purpose of this study was to examine and analyze the effect of job satisfaction and organizational commitment to employee performance PT. Philips Batam. This research method is descriptive quantitative method or form of numbers that explain and processing a data collected by questionnaire. Mechanical sampling probability sampling with simple random sampling method, with survey through
\end{abstract}


questionnaires. Furthermore, the data that has been collected in this study were analyzed by multiple linear regression and processed using SPSS 21. The results of the test, partially known that for the independent variable is job satisfaction (X1) positive and significant impact on employee performance and organizational commitment (X2) positive and significant impact on employee performance. From the F test results indicate job satisfaction variables (X1) and organizational commitment (X2) simultaneously significantly influence employee performance variables.

\section{Keywords: Job Satisfaction, Organizational Commitment and Employee Performance}

\section{PENDAHULUAN}

Suatu organisasi baik perusahaan maupun instansi dalam melakukan aktivitasnya sudah tentu memerlukan sumber daya manusia yang mendukung usaha pencapaian tujuan yang telah ditetapkan suatu organisasi ataupun perusahaan. Bagaimanapun lengkapnya dan canggihnya sumber daya non-manusia yang dimiliki oleh suatu perusahaan, tidaklah menjadi jaminan bagi perusahaan tersebut untuk mencapai suatu keberhasilan. Jaminan untuk mendapatkan keberhasilan, lebih banyak ditentukan oleh sumber daya manusia yang mengelola, mengendalikan, dan mendayagunakan sumber-sumber daya non-manusia yang dimilikinya. Oleh karena itu masalah karyawan merupakan masalah besar yang harus mendapatkan suatu perhatian yang cukup besar bagi perusahaan.

Peningkatan kinerja merupakan hal yang diinginkan baik dari pihak pemberi kerja maupun para pekerja. Pemberi kerja menginginkan kinerja karyawannya baik untuk peningkatan hasil kerja dan keuntungan perusahaan. Disisi lain, para pekerja berkepentingan untuk pengembangan diri dan promosi pekerjaan. Sumber daya manusia memegang peranan yang sangat penting, karena faktor manusia menentukan kelangsungan hidup suatu perusahaan.Tidak ada satupun perusahaan yang tidak melibatkan manusia dan dapat merealisasikan tujuannya.

Menurut Wilson (2012: 4) karyawan atau sumber daya manusia memiliki peran yang penting dalam pencapaian tujuan dalam organisasi dan merupakan satu-satunya aset perusahaan yang bernafas atau hidup disamping aset lain yang tidak bernafas atau bersifat kebendaan seperti modal, bangunan, gedung, mesin, peralatan kantor dan persediaan barang. 
Tanpa sumber daya manusia yang berkualitas dan berkompeten dengan pekerjaan, perusahaan tidak akan mengalami kemajuan. Berbagai proyeksi mengarah pada sumber daya manusia yang berkepribadian dan konsisten dalam pekerjaannya. Manusia sepertinya tidak merasa puas dengan apa yang didapat, seperti jabatan dan gaji yang tinggi diperusahaan.

Oleh karena itu tugas dari Manajer Personalia adalah harus dapat menyesuaikan antara keinginan karyawan dengan tujuan dari perusahaan. Dengan kepuasan kerja seorang pegawai dapat merasakan pekerjaannya apakah menyenangkan atau tidak menyenangkan untuk dikerjakan. Menurut Robbins (2003:78) dalam buku Wibowo (2011) kepuasan adalah sikap umum terhadap pekerjaan seseorang yang menunjukkan perbedaan antara jumlah penghargaan yang diterima pekerja dan jumlah yang mereka yakini seharusnya mereka terima. Bermacammacam sikap seseorang terhadap pekerjaannya mencerminkan pengalaman yang menyenangkan dan tidak menyenangkan dalam pekerjaannya serta harapan-harapannya terhadap pengalaman masa depan. Pekerjaan yang menyenangkan untuk dikerjakan dapat dikatakan bahwa pekerjaan itu memberi kepuasaan bagi pemangkunya. Kejadian sebaliknya, ketidakpuasan akan diperoleh bila suatu pekerjaan tidak menyenangkan untuk dikerjakan.

Kepuasan kerja merupakan bagian penting dari pengalaman hidup karyawan dalam bekerja, artinya terkait dengan seorang karyawan menerima cukup imbalan intrinsik dan ekstrinsik mendorong karyawan untuk tetap ditempat kerja mereka dan terus menghabiskan sebagian besar waktu untuk pemenuhan tugasnya. Kepuasan kerja terdiri dari tiga aspek penting, kepuasan kerja merupakan suatu fungsi nilai, persepsi, perbedaan menurut tenaga kerja mengenai yang seharusnya mereka terima. Kepuasan kerja merupakan salah satu aspek yang penting untuk dipahami oleh pengelola organisasi. Karyawan yang memiliki tingkat kepuasan kerja yang cukup dalam perusahaan memiliki peran penting dalam pencapaian tujuan perusahaan. Betapapun sempurnanya rencana-rencana organisasi dan pengawasan kepada karyawan, bila mereka tidak dapat menjalankan tugasnya dengan penuh tanggung jawab maka suatu perusahaan tidak akan mencapai hasil sebanyak yang sebenarnya dapat dicapainya. Hal tersebut berarti bahwa faktor manusia cukup berperan dalam mencapai hasil sesuai dengan tujuan organisasi. Mewujudkan kepuasan kerja bagi karyawan adalah merupakan kewajiban bagi setiap pimpinan organisasi. Kepuasan kerja perlu didahului oleh 
penegasan bahwa masalah kepuasan kerja bukanlah hal yang sederhana, baik dalam arti konsepnya maupun dalam arti analisisnya, karena kepuasan mempunyai konotasi yang beranega ragam Faktor-faktor kepuasan disebut satisfier, adalah kemajuan, pengakuan, tanggung jawab, perkembangan karier, dan pekerjaan itu sendiri. Apabila faktor-faktor tersebut ditingkatkan akan membantu perbaikan prestasi, menurunkan perputaran dan absensi kerja, dan menunjang sikap yang baik terhadap manajemen. Sedangkan faktor-faktor yang menyebabkan ketidakpuasan (dissatisfier) meliputi hal-hal seperti kondisi dan kemudahan dalam pekerjaan, kebijakan-kebijakan administraif, hubungan dengan manajemen, ketrampilan teknis para penyelia, sistem penggajian stabilitas pekerjaan, dan hubungan dengan rekan kerja.

PT. Philips Batam sebagai salah satu perusahaan besar yang ada di Batam akan menerapkan dan mempertahankan kelangsungan kegiatan dalam perusahaan agar tetap komitmen dan lancar, meningkatkan daya saing serta citra perusahan dimata konsumen di seluruh dunia. Dalam pelaksanaan pekerjaanya, PT. Philips Batam akan terus berupaya memberikan kepuasan kerja pada karyawan, salah satu usaha yang dilakukan adalah melalui pemberian bonus setiap tahun apabila target dalam penjualan produk ke pelanggan, mengadakan pelatihan-pelatihan baik secara internal diperusahaan ataupun eksternal dan memberikan beasiswa untuk karyawan yang berprestasi dengan mengirimkan keperguruan tinggi yang berada di Batam. Sebagai salah satu perusahaan yang bertujuan untuk mendapatkan profit dan laba maka diperlukan kinerja yang baik dari perusahaan dan hal tersebut ditunjang oleh kinerja yang maksimal yang dimiliki oleh sumber daya manusianya. Salah satu masalah yang mengganggu kinerja karyawan PT. Philips Batam adalah masalah kepuasan kerja karyawan, yaitu lingkungan kerja yang tidak nyaman, beban pekerjaan yang tidak merata antara sesama karyawan, hubungan yang tidak harmonis antara karyawan dan pimpinan, serta kompetensi karyawan yang tidak sesuai dengan jabatan yang di pegangnya.

Permasalahan pada kepuasan kerja tersebut akan berdampak pada beberapa karyawan yang sering absen pada saat jam kerja, telat datang kerja, tidak mengikuti instruksi dari atasannya dan sering melanggar peraturan yang ada, selalu ingin pindah kerja dan kurang bersemangat dalam melakukan aktivitas pekerjaannya, serta banyak lagi pelanggaran kedisiplinan yang dilakukan oleh karyawan. 
Faktor lain yang juga mempengaruhi kinerja karyawan adalah komitmen perusahaan. Menurut Sopiah (2008: 157) menyimpulkan bahwa komitmen organisasi adalah suatu ikatan psikologis karyawan pada organisasi yang ditandai dengan adanya kepercayaan dan penerimaan yang kuat atas tujuan dan nilai-nilai organisasi, kemauan untuk mengusahakan tercapainya kepentingan organisasi dan keinginan yang kuat untuk mempertahankan kedudukan sebagai anggota organisasi. Namun demikian sifat dari kondisi psikologis untuk tiap bentuk komitmen sangat berbeda. Komitmen organisasi didefinisikan sebagai tingkat kekerapan identifikasi dan tingkat keterikatan individu kepada organisasi tertentu yang dicerminkan dengan karakteristik : adanya keyakinan yang kuat dan penerimaan atas nilai dan tujuan organisasi serta adanya keinginan yang pasti untuk mempertahankan keikutsertaan dalam organisasi.

Menurut Sopiah (2008: 156) mengemukakan bahwa orang-orang yang relatif puas dengan pekerjaannya akan lebih berkomitmen terhadap organisasi. Karyawan akan memiliki komitmen organisasi yang tinggi ketika merasa puas dengan pekerjaannya, supervisi, gaji, promosi dan rekan kerja. Menurut Meyer, Allen, dan Smith dalam Spector (1998) dalam buku Sopiah (2008: 157) mengemukakan bahwa ada tiga komponen komitmen organisasional yaitu affective commitment, terjadi apabila karyawan ingin menjadi bagian dari organisasi karena adanya ikatan emosional, continuance commitment, muncul apabila karyawan tetap bertahan pada suatu organisasi karena membutuhkan gaji dan keuntungan-keuntungan lain, atau karena karyawan tersebut tidak menemukan pekerjaan lain, normative commitment, timbul dari nilainilai dalam diri karyawan.

Komitmen kerja (work commitment) dan kepuasan kerja (job satisfaction) adalah topik yang populer dalam penelitian mengenai pekerjaan berhubungan dengan sikap (attitude). Menekankan perlunya komitmen dengan asumsi bahwa komitmen mendorong pilihan kebiasaan pegawai yang mendukung perusahaan yang vital untuk kerja yang efektif.

Penelitian ini bertujuan ini untuk mengetahui pengaruh kepuasan kerja terhadap kinerja karyawan PT Philips Batam, mengetahui pengaruh komitmen organisasional terhadap kinerja karyawan PT Philips Batam dan mengetahui pengaruh kepuasan kerja dan komitmen organisasional secara simultan berpengaruh terhadap kinerja karyawan PT Philips Batam. 
Penelitian ini bermanfaat untuk memperoleh jawaban atas rumusan masalah dan memperkuat teori yang sudah ada, membuktikan hasil dari penelitian terdahulu, dan menjadi referensi bagi peneliti berikutnya. Selain itu, penelitian ini diharapkan dapat menjadi masukan bagi perusahaan untuk dapat lebih selektif lagi dalam kepuasan kerja dan komitmen organisasional sehingga dapat meningkatan kinerja karyawan untuk kesejahteraan karyawan serta perusahaan dalam memperoleh keuntungan yang maksimal.

\section{Kajian Pustaka Dan Pengembangan Hipotesis}

Menurut Wexley dan Yukl (2003) dalam buku Wilson (2012: 327) menyatakan bahwa dengan kepuasan kerja seorang pegawai dapat merasakan pekerjaannya apakah menyenangkan atau tidak menyenangkan untuk dikerjakan. Setiap orang yang bekerja mengharapkan memperoleh kepuasan kerja dari tempatnya bekerja. Pada dasarnya kepuasan kerja merupakan hal yang bersifat individual akan memiliki tingkat kepuasan yang berbeda-beda sesuai dengan nilai-nilai yang berlaku dalam diri setiap individu. Semakin banyak aspek dalam pekerjaan yang sesuai dengan keinginan individu, maka semakin tinggi tingkat kepuasan yang dirasakan.

Menurut Robbins (2003) dalam buku Wibowo (2011: 120) menyatakan kepuasan kerja dapat didefinisikan sebagai sikap umum individu terhadap pekerjaannya. Pekerjaan membutuhkan interaksi dengan rekan kerja dan para atasan, mematuhi peraturan-peraturan dan kebijakan-kebijakan organisasi, memenuhi standar kinerja, hidup dengan suasana yang sering kali kurang dari ideal dan semacamnya. Hal ini berarti penilaian karyawan atas seberapa puas atau tidak puas dirinya dengan pekerjaannya adalah perhitungan rumit dari sejumlah elemen pekerjaan yang sensitif.

Menurut Wexley dan Yukl (2003) dalam buku Wilson (2012: 328) menyatakan bahwa beberapa teori tentang kepuasan kerja, yaitu:

\section{Teori Dua Faktor (Two Factor Teory)}

Teori ini menganjurkan bahwa kepuasaan dan ketidakpuasaan merupakan bagian dari kelompok variabel yang berbeda yaitu motivator dan hygiene factors. Ketidakpuasan dihubungkan dengan kondisi disekitar pekerjaan (seperti kondisi kerja, upah, keamanan, kualitas pengawasan dan hubungan dengan orang lain) dan bukan dengan pekerjaan itu 
sendiri. Karena faktor mencegah reaksi negatif dinamakan sebagai hygiene atau maintenance factors.

Sebaliknya kepuasan ditarik dari faktor yang terkait dengan pekerjaan itu sendiri atau hasil langsung seperti sifat pekerjaan, prestasi dalam pekerjaan, peluang promosi dan kesempatan untuk pengembangan diri dan pengakuan. Karena faktor ini berkaitan dengan tingkat kepuasan kerja tinggi dinamakan motivators.

Menurut teori ini kepuasan kerja terjadi pada tingkatan dimana hasil pekerjaan diterima individu seperti diharapkan. Semakin banyak orang menerima hasil, akan semakin puas dan sebaliknya. Kunci menuju kepuasan pada teori ini adalah perbedaan antara aspek pekerjaan yang dimiliki dengan yang diinginkan seseorang. Semakin besar perbedaaan, semakin rendah kepuasan.

Menurut Mathis dan Jakson (2000) dalam buku Sopiah (2008: 155) memberikan definisi,"Organizational Commitment is the degree to which employees believe in and accept organizational goals and desire to remain with the organization”. (Komitmen organisasional adalah derajat yang mana karyawan percaya dan menerima tujuan-tujuan organisasi dan akan tetap tinggal atau tidak akan meninggalkan organisasi).

Menurut Sopiah (2008: 157) menyebut komitmen organisasional adalah suatu ikatan psikologis karyawan pada organisasi yang ditandai dengan adanya kepercayaan dan penerimaan yang kuat atas tujuan dan nilai-nilai organisasi, kemauan untuk mengusahakan tercapainya kepentingan organisasi dan keinginan yang kuat untuk mempertahankan kedudukan sebagai anggota organisasi. Komitmen organisasional merupakan identifikasi dan keterlibatan seseorang yang relatif kuat terhadap organisasi. Komitmen organisasional adalah keinginan anggota organisasi untuk tetap mempertahankan keanggotaannya dalam organisasi dan bersedia berusaha keras bagi pencapaian tujuan organisasi.

Jadi pengertian komitmen lebih dari sekedar menjadi anggota saja, tetapi lebih dari itu orang akan bersedia untuk mengusahakan pada derajat upaya yang tinggi bagi kepentingan organisasi, demi memperlancar mencapai tujuan organisasi. 
Mahsum (2009: 25) dalam Sembiring (2012: 80) kinerja adalah gambaran mengenai tingkat pencapaian pelaksanaan suatu kegiatan/program/kebijakan dalam mewujudkan sasaran, tujuan, misi dan visi organisasi yang tertuang dalam strategic planning.

Komitmen pegawai pada organisasi tidak terjadi begitu saja, tetapi melalui proses yang cukup panjang dan bertahap. Steers (1985) dalam buku Sopiah (2008) menyatakan tiga faktor yang mempengaruhi komitmen seorang karyawan antara lain:

Ciri pribadi pekerja termasuk masa jabatannya dalam organisasi, dan variasi kebutuhan dan keinginan yang berbeda dari tiap karyawan.

Ciri pekerjaan, seperti identitas tugas dan kesempatan berinteraksi dengan rekan sekerja; dan pengalaman kerja, seperti keterandalan organisasi di masa lampau dan cara pekerja-pekerja lain mengutarakan dan membicarakan perasaannya tentang organisasi

Dibawah ini adalah aspek-aspek dari komitmen organisasional adalah sebagai berikut:

Identifikasi yang berwujud dalam bentuk kepercayaan anggota terhadap organisasi. Guna menumbuhkan identifikasi dilakukan dengan memodifikasi tujuan organisasi/organisasi, sehingga mencakup beberapa tujuan pribadi para anggota atau dengan kata lain organisasi memasukan pula kebutuhan dan keinginan anggotan dalam tujuan organisasi atau organisasi. Hal ini akan menumbuhkan suasana saling mendukung di antara para anggota dengan organisasi. Lebih lanjut membuat anggota dengan rela menyumbangkan tenaga, waktu, dan pikiran bagi tercapainya tujuan organisasi.

Keterlibatan atau partisipasi anggota dalam aktivitas-aktivitas kerja penting untuk diperhatikan karena adanya keterlibatan anggota menyebabkan mereka bekerja sama, baik dengan pimpinan atau rekan kerja. Cara yang dapat dipakai untuk memancing keterlibatan anggota adalah dengan memasukan mereka dalam berbagai kesempatan pembuatan keputusan yang dapat menumbuhkan keyakinan pada anggota bahwa apa yang telah diputuskan adalah keputusan bersama. Juga anggota merasakan bahwa mereka diterima sebagai bagian dari organisasi, dan konsekuensi lebih lanjut, mereka merasa wajib untuk melaksanakan bersama apa yang telah mereka putuskan, karena adanya rasa keterikatan dengan apa yang mereka ciptakan. Hasil yang dirasakan bahwa tingkat kehadiran anggota yang memiliki rasa keterlibatan tinggi umumnya akan selalu disiplin dalam bekerja. 
Loyalitas anggota terhadap organisasi memiliki makna ksesediaan seseorang untuk bisa melanggengkan hubungannya dengan organisasi kalau perlu dengan mengorbankan kepentingan pribadinya tanpa mengharapkan apa pun. Keinginan anggota untuk mempertahankan diri bekerja dalam organisasi adalah hal yang dapat menunjang komitmen anggota terhadap organisasi di mana mereka bekerja. Hal ini di upayakan bila anggota merasakan adanya keamanan dan kepuasan dalam tempat kerjanya.

Menurut Sopiah (2008: 156) menyatakan arti dari komitmen terhadap organisasi. Ada 3 (tiga) area perasaan atau perilaku terkait dengan perusahaan tempat seseorang bekerja.

Kepercayaan, pada area ini seseorang melakukan penerimaan bahwa organisasi tempat bekerja atau tujuan-tujuan organisasi didalamnya merupakan sebuah nilai yang diyakini kebenarannya.

Keinginan untuk bekerja atau berusaha di dalam organisasi sebagai kontrak hidupnya. Pada konteks ini orang akan memberikan waktu, kesempatan dan kegiatan pribadinya untuk bekerja diorganisasi atau dikorbankan ke organisasi tanpa mengharapkan imbalan personal.

Keinginan untuk bertahan dan menjadi bagian dari organisasi.

Wilson (2012: 231) mengatakan, bahwa istilah kinerja adalah hasil pekerjaan yang dicapai seseorang berdasarkan persyaratan-persyaratan pekerjaan (job requirement). Suatu pekerjaan mempunyai persyaratan tertentu untuk dapat dilakukan dalam mencapai tujuan yang disebut juga sebagai standar pekerjaan (job standard).

Rivai (2006: 309) mengatakan bahwa kinerja merupakan perilaku nyata yang ditampilkan setiap orang sebagai prestasi kerja yang dihasilkan oleh karyawan sesuai dengan perannya dalam perusahaan.

Berdasarkan pendapat beberapa ahli tersebut, dapat disimpulkan bahwa penilaian prestasi kerja (kinerja) adalah penilaian yang dilakukan secara sistematis untuk mengetahui hasil pekerjaan karyawan dan kinerja organisasi. Disamping itu, juga untuk menentukan pelatihan kerja secara tepat, memberikan tanggapan yang lebih baik di masa mendatang dan sebagai dasar untuk menentukan kebijakan dalam hal promosi jabatan dan penentuan imbalan. Tujuan dari penilaian prestasi kerja (kinerja) adalah untuk memperbaiki atau meningkatkan kinerja organisasi dari SDM organisasi secara spesifik. 
Penilaian kinerja adalah proses yang dilakukan organisasi untuk mengevaluasi atau menilai keberhasilan karyawan dalam melaksanakan tugasnya, Wilson (2012: 231). Penilaian dapat dilakukan dengan membandingkan hasil kerja yang dicapai karyawan dengan standar pekerjaan. Bila hasil kerja yang diperoleh sampai atau melebihi standar pekerjaan dapat dikatakan kinerja seorang karyawan termasuk pada kategori baik. Demikian sebaliknya, seorang karyawan yang hasil pekerjaannya tidak mencapai standar pekerjaan termasuk pada kinerja yang tidak baik atau berkinerja rendah.

Menurut Handoko (2008: 138-139), penilaian hendaknya memberikan gambaran akurat mengenai prestasi kerja karyawan sehingga untuk mencapai tujuan ini sistem penilaian harus mempunyai hubungan dengan pekerjaan (job related), praktis, mempunyai standarstandar dan menggunakan berbagai ukuran yang dapat diandalkan. Job related berarti bahwa sistem menilai perilaku-perilaku kritis yang mewujudkan keberhasilan perusahaan. Sedangkan suatu sistem disebut praktis bila dipahami atau dimengerti oleh para penilai dan karyawan. Di samping harus job related dan praktis, evaluasi prestasi kerja memerlukan standar-standar pelaksanaan kerja (performance standard) dengan mana prestasi kerja diukur. Agar efektif, standart hendaknya berhubungan dengan hasil-hasil yang diinginkan pada setiap pekerjaan. Lebih lanjut, evaluasi juga memerlukan ukuran-ukuran prestasi kerja yang dapat diandalkan (performance measures). Berbagai ukuran ini, agar berguna, harus mudah digunakan, reliabel dan melaporkan perilaku-perilaku kritis yang menentukan prestasi-prestasi kerja.

Penilaian kinerja (prestasi kerja) merupakan proses subjektif yang menyangkut penilaian manusia. Dikatakan penilaian kinerja subyektif, karena kebanyakan pekerjaan benarbenar tidak mungkin diukur secara obyektif, hal ini disebabkan beberapa alasan, termasuk alasan kerumitan dalam tugas pengukuran, lingkaran yang berubah-ubah, dan kesulitan dalam merumuskan tugas dan pekerjaan individual tenaga kerja secara rinci. Dengan demikian, penilaian kinerja sangat mungkin keliru dan sangat mudah dipengaruhi oleh sumber yang tidak aktual. Tidak sedikit sumber tersebut mempengaruhi proses penilaian sehingga harus diperhitungkan dan dipertimbangkan dengan wajar. Penilaian kinerja dianggap memenuhi sasaran apabila memiliki dampak yang baik pada tenaga kerja yang baru dinilai kinerjanya. 
Proses penilaian prestasi kerja menghasilkan suatu evaluasi atau prestasi kerja karyawan di waktu yang lalu dan atau prediksi prestasi kerja di waktu yang akan datang. Proses penilaian ini kurang mempunyai nilai bila para karyawan tidak menerima umpan balik mengenai prestasi kerja mereka. Tanpa umpan balik, perilaku karyawan tidak akan dapat diperbaiki. Oleh karena itu, bagian kritis proses penilaian adalah wawancara eksklusif. Menurut Handoko (2008: 152-153), wawancara eksklusif adalah proses peninjauan kembali prestasi kerja yang memberikan kepada karyawan umpan balik tentang prestasi kerja di masa lalu dan potensi mereka. Penilai bisa memberikan umpan balik ini melalui beberapa pendekatan:

\section{Tell and Sell Approach}

Mereview prestasi kerja karyawan dan mencoba untuk meyakinkan karyawan untuk berprestasi lebih baik. Pendekatan ini paling baik digunakan untuk para karyawan baru.

\section{Tell and Listen Approach}

Memungkinkan karyawan untuk menjelaskan berbagia alasan latar belakang dan perasaan defensif mengenai prestasi kerja. Ini bermaksud untuk mengatasi reaksi-reaksi tersebut dengan konseling tentang bagaimana cara berprestasi lebih baik.

\section{Problem Solving Approach}

Mengidentifikasi masalah-masalah yang menggangu prestasi kerja karyawan. Kemudian melalui latihan, coaching atau konseling, upaya-upaya dilakukan untuk memecahkan penyimpangan-penyimpangan (sering diikuti dengan penetapan sasaran-sasaran prestasi kerja di waktu yang akan datang). Berdasarkan uraian-uraian di atas maka unsur-unsur kinerja yang akan dilihat dalam penelitian ini adalah (1) prestasi, (2) ketaatan, dan (3) prakarsa. Dengan alasan ketiga unsur tersebut diasumsikan sudah cukup mewakili unsur-unsur kinerja yang akan dikaji dalam penelitian ini. Hal ini mengingat sangat luasnya kajian teoritis tentang kinerja dan keterbatasan penulis untuk dapat menggali seluruh unsur yang ada di dalamnya.

Berdasarkan paparan di atas, hipotesis yang dikembangkan untuk penelitian ini adalah sebagai berikut. 
H1: Kepuasan kerja berpengaruh positif dan signifikan terhadap kinerja karyawan PT. Philips Batam.

H2: Komitmen organisasional berpengaruh positif dan signifikan terhadap kinerja karyawan PT. Philips Batam.

H3: Kepuasan kerja dan komitmen organisasional secara simultan berpengaruh signifikan terhadap kinerja karyawan PT. Philips Batam.

\section{METODOLOGI}

\section{Teknik Sampling}

Penelitian ini dirancang untuk mengamati dan menganalisis pengaruh kepuasan kerja dan komitmen organisasional terhadap kinerja karyawan PT Philips Batam. Teknik sampling yang digunakan dalam penelitian ini adalah Probability Sampling, yaitu teknik pengambilan sampling yang memberikan peluang sama bagi setiap anggota populasi untuk diteliti menjadi anggota sampel dengan metode Simple Random Sampling. Menurut Sugiyono (2012: 82) simple random sampling adalah teknik pengambilan anggota sampel yang dilakukan secara acak tanpa memperhatikan strata yang ada dalam populasi tersebut.

Sampel pada penelitian ini adalah seluruh jumlah responden tentang kinerja karyawan yang ada di PT Philips Batam. Alat yang digunakan dalam pengumpulan data dalam penelitian ini adalah berupa daftar petanyaan atau penyataan (kuesioner) yakni dengan menyebarkan daftar pertanyaan atau penyataan (kuesioner) tersebut kepada para responden.

\section{Data Demografi Responden}

Data penelitian ini disebarkan sebanyak 334 buah kuesioner dengan responsi sebesar 334 buah (100 persen). Dari data tersebut, menandakan bahwa tidak ada data dalam penelitian ini yang missing atau hilang. Data demografi responden dapat dilihat dalam Tabel 1. 
Tabel 1

Data Demografi Responden

\begin{tabular}{llll}
\hline Keterangan & \multicolumn{1}{c}{ Kategori } & \multicolumn{2}{c}{ Responden } \\
& & Jumlah & Presentase \\
\hline Jenis Kelamin & Wanita & 284 & 85 \\
& Pria & 50 & 15 \\
Usia & $<21$ tahun & 140 & 41,9 \\
& $21-30$ tahun & 177 & 53 \\
& 31-40 tahun & 13 & 3,9 \\
\multirow{3}{*}{ Masa Kerja } & 41-50 tahun & 4 & 1,2 \\
& $<5$ tahun & 319 & 95,5 \\
& $>5$ tahun & 15 & 4,5 \\
& SMP & 0 & 0 \\
& SMA/SMK & 324 & 97 \\
& D3 & 3 & 0,9 \\
& S1 & 7 & 2,1 \\
& S2 & 0 & 0 \\
\hline
\end{tabular}

Sumber: Data Primer diolah

\section{Pengujian Hipotesis}

Penelitian ini mengamati 3 variabel. Variabel pertama adalah kinerja karyawan (Y) sebagai variabel dependen (terikat). Variabel berikutnya adalah kepuasan kerja (X1) dan komitmen organisasional (X2) sebagai variabel independen (bebas). Tiap-tiap veriabel akan diukur dengan instrument yang digunakan oleh penelitian sebelumnya.

\section{Definisi Operasional Variabel}

Definisi operasional dan instrument-instrumen pengukuran yang digunakan dalam penelitian ini berdasarkan penelitian sebelumnya dan sedikit dimodifikasi untuk penyesuaian terhadap penelitian ini. Instrumen diadopsi dari penelitian Devi, Eva Kris Diana (2009), 
penelitian Ratnawati, Intan dan Chaterina, M.T (2012), serta dari penelitian Tobing (2009), dan penelitian Ratnasari, CChristiananta, dan Eliyana (2012):

\section{Kepuasan Kerja}

Kepuasan kerja dapat didefinisikan sebagai sikap umum individu terhadap pekerjaannya. Kepuasan kerja dalam penelitian ini menggunakan lima indikator yang mencirikan kepuasan kerja yaitu kepuasan terhadap kemajuan, kepuasan terhadap pengakuan, kepuasan terhadap tanggung jawab, kepuasan terhadap pengembangan karir dan kepuasan terhadap pekerjaan itu sendiri. Ada lima belas butir pertanyaan untuk variabel kepuasan kerja.

\section{Komitmen Organisasional}

Komitmen organisasional adalah suatu ikatan psikologis karyawan pada organisasi yang ditandai dengan adanya kepercayaan dan penerimaan yang kuat atas tujuan dan nilai-nilai organisasi, kemauan untuk mengusahakan tercapainya kepentingan organisasi dan keinginan yang kuat untuk mempertahankan kedudukan sebagai anggota organisasi. Komitmen organisasional dalam penelitian ini menggunakan empat indikator yaitu faktor personal, karakteristik pekerjaan, karakteristik terstruktur dan pengalaman kerja. Ada lima belas butir pertanyaan dalam variabel komitmen organisasional.

3. Kinerja Karyawan

Kinerja karyawan adalah hasil pekerjaan yang dicapai seseorang berdasarkan persyaratanpersyaratan pekerjaan (job requirement). Kinerja karyawan dalam penelitian ini menggunakan lima indicator yaitu jumlah pekerjaan, kualitas pekerjaan, ketepatan waktu, kehadiran, dan kemampuan kerja sama. Ada lima belas butir pertanyaan dalam variabel kinerja karyawan.

\section{PEMBAHASAN}

\section{Uji Kualitas Data}

Uji Kualitas data dalam penelitian ini menggunakan dua pengujian yaitu uji validitas dan uji reliabilitas.

\section{Uji Validitas Data}

Vadilitas adalah suatu ukuran yang menunjukkan tingkat-tingkat kevalidan suatu instrument. Suatu instrument yang valid mempunyai vadilitas yang tinggi, sebaliknya, 
instrument yang kurang valid berarti memiliki validitas rendah. Pengujian ini menggunakan rumus Pearson Product Moment, sebagai berikut.

1. Jika $\mathrm{r}$ hitung $\geq \mathrm{r}$ tabel, maka item-item pada pertanyaan dinyatakan berkorelasi signifikan terhadap skor total item tersebut, maka item dinyatakan valid.

2. Jika $\mathrm{r}$ hitung < r tabel, maka item-item pada pertanyaan dinyatakan tidak berkorelasi signifikan terhadap skor total item tersebut, maka item dinyatakan tidak valid.

Berdasarkan uji validitas, seluruh hasil pernyataan lebih besar dari nilai $\mathrm{r}$ tabel, maka pernyataan dinyatakan valid.

\section{Uji Reliabilitas Data}

Uji reliabilitas adalah istilah yang dipakai untuk menunjukkan sejauh mana suatu hasil pengukuran relatif konsisten apabila pengukuran diulangi dua kali atau lebih. Kriteria Uji Reliabilitas adalah Cronbach's Alpha harus lebih besar dibandingkan dengan 0,60. Berdasarkan uji reliabilitas, seluruh instrument-instrumen yang digunakan dalam penelitian ini reliable

\section{Uji Asumsi}

Uji asumsi ini digunakan digunakan dalam penelitian ini untuk menguji tentang pengaruh dari varibel, sehingga alat uji hipotesis menggunakan regresi. Uji ini terdiri dari Normalitas, Uji Komogorov-Smirnov dan Multikolinearitas.

\section{Uji Normalitas}

Dalam pengujian normalitas apabila suatu data yang berdistribusi normal akan membentuk suatu kurva yang kalau digambarkan akan berbentuk lonceng (bell shaped curve). Suatu data dikatakan tidak normal jika memiliki nilai data yang ekstrim, atau biasanya jumlah data terlalu sedikit.

\section{Uji Komogorov-Smirnov}

Dalam pengujian ini apabila kurva nilai residual terstandarisasi memiliki sebaran data normal jika nilai Kolmogorov-Smirnov Z $<$ Z tabel atau nilai Asymp.Sig (2 tailed) $>\propto$. Menganakisa hasil uji diatas diambil kesimpulan bahwa data memiliki distribusi normal karena nilai Kolmogorov-Smirnov memiliki tingkat signifikasi Z > 0,05. 


\section{Uji Multikolinearitas}

Pengujian multikolinearitas dilakukan untuk memastikan tidak ada korelasi antara variabel independen. Gejala multikolinearitas dapat diketahui melalui suatu uji yang dapat mendeteksi dan menguji apakah persamaan yang dibentuk terjadi multikolinearitas. Salah satu cara untuk mendeteksi gejala multikolinearitas adalah dengan menggunakan Variance Inflation Factor (VIF). Caranya dengan melihat variabel bebas terhadap variabel terikatnya, berdasarkan nilai VIF tersebut, jika nilai VIF kurang dari 10, maka menunjukkan model tidak terdapat gejala multikolinearitas.

\section{Pengujian Hipotesis}

Pengujian hipotesis dilakukan secara parsial dan bersama-sama (simultan). Pengaruh variabel independen terhadap variabel dependen diuji dengan tingkat kepercayaan 95\% atau $\alpha=5 \%$. Pengujian dilakukan dengan menggunakan software pengolahan data SPSS 21 .

Berikut ini model persamaan regresi linier berganda:

$\mathrm{Y}=\mathrm{a}+\mathrm{b}_{1} \mathrm{x}_{1}+\mathrm{b}_{2} \mathrm{X}_{2}+\mathrm{b}_{3} \mathrm{X}_{3}+\ldots .+\mathrm{b}_{\mathrm{n}} \mathrm{x}_{\mathrm{n}}$

Keterangan:

$\mathrm{Y}=$ kinerja karyawan

$\mathrm{a}=$ nilai konstanta

$\mathrm{b}=$ nilai koefisien regresi

$\mathrm{X}_{1}=$ variabel independen pertama (kepuasan kerja)

$\mathrm{X}_{2}=$ variabel independen kedua (komitmen organisasional)

$\mathrm{Xn}=$ variabel independen ke-n

Hasil analisis regresi persamaan yang digunakan dalam penelitian ini dapat dilihat dalam lampiran, sedangkan ringkasan hasil regresi bisa dilihat dalam Tabel 2 berikut ini. 
Tabel 2 Hasil Analisis Regresi

\begin{tabular}{lllcccc} 
Variabel & Koefisien & T & Sign. & F & Sign & R Square \\
\hline Kepuasan Kerja & 0,317 & 7,639 & 0,000 & 137,780 & 0,000 & 0,454 \\
Komitmen & 0,318 & 9,007 & 0,000 & & & \\
Organisasional & & & & & & \\
& & & & & & \\
\hline
\end{tabular}

Sumber: data primer diolah

Berdasarkan Tabel 2 dapat diketahui sebagai berikut:

1. Nilai thitung untuk variabel kepuasan kerja $(7,639)$ lebih besar dibandingkan dengan $t$ tabel $(1,972)$ atau nilai sig t $(0,000)$ lebih kecil dari alpha $(0,05)$. Berdasarkan hasil yang diperoleh maka H0 ditolak dan H1 diterima untuk variabel kepuasan kerja, dengan demikian maka secara partial variabel kepuasan kerja berpengaruh secara signifikan terhadap kinerja karyawan.

2. Nilai t hitung untuk variabel komitmen organisasional $(9,007)$ lebih besar dibandingkan dengan t tabel $(1,972)$ atau nilai sig $t(0,000)$ lebih kecil dari alpha $(0,005)$. Berdasarkan hasil yang telah diperoleh maka $\mathrm{H} 0$ ditolak dan $\mathrm{H} 2$ diterima untuk variabel komitmen organisasional , dengan demikian maka secara parsial variabel komitmen organisasional berpengaruh secara signifikan terhadap kinerja karyawan. Hasil statistik yang telah dikemukakan di atas menunjukan bahwa secara parsial komitmen organisasional berpengaruh signifikan dalam mempengaruhi kinerja karyawan pada PT Philips Industrial Batam.

3. Berdasarkan tabel 2 dapat diketahui bahwa thitung $=137,780$ dan $\mathrm{F}$ tabel $=3,05$ dalam hal ini $\mathrm{F}$ hitung lebih besar dari $\mathrm{F}$ tabel dan nilai signifikan adalah 0,000 lebih kecil dari nilai alpha 0,05, sehingga keputusan yang diambil adalah H0 ditolak dan H3 diterima. Diterimanya hipotesis alternatif menunjukkan variabel bebas kepuasan kerja (X1) dan komitmen organisasional (X2) mampu menjelaskan keragaman dari variabel terikat kinerja 
karyawan (Y). Dalam hal ini variabel kepuasan kerja dan komitmen organisasional secara simultan berpengaruh signifikan terhadap kinerja karyawan.

4. Dari data 2 di atas, dapat diketahui bahwa nilai $\mathrm{R}^{2}$ sebesar 0,674. Ini berarti persentase kepuasan kerja (X1) dan komitmen organisasional (X2), sebesar 45,4 \% atau variasi variabel kinerja (Y) dapat dijelaskan oleh variasi variabel kepuasan kerja (X1) dan komitmen organisasional (X2) sebesar 45,4 \% sedangkan sisanya sebanyak 54,6 \% dijelaskan oleh variabel lain yang tidak dimasukkan dalam model penelitian ini.

\section{KESIMPULAN DAN SARAN}

\section{Kesimpulan}

Hasil penelitian pada uji t membuktikan bahwa secara parsial kepuasan kerja dan komitmen organisasional berpengaruh signifikan dalam mempengaruhi kinerja karyawan pada PT Philips Industrial Batam. Hasil pengujian pada uji F dapat dilihat bahwa secara simultan kepuasan kerja dan komitmen organisasional berpengaruh signifikan terhadap kinerja karyawan PT Philips Batam.

\section{Saran}

Penelitian ini diharapkan dapat menjadi kontribusi bagi perusahaan untuk dapat lebih selektif lagi dalam kepuasan kerja dan komitmen organisasional sehingga dapat meningkatan kinerja karyawan untuk kesejahteraan karyawan serta perusahaan dalam memperoleh keuntungan yang maksimal.

\section{REFERENSI}

Ashrahenny dan Ratnasari, Sri Langgeng. 2016. Pengaruh Gaya Kepemimpinan Dan Komunikasi Terhadap Kinerja Karyawan PT. Hi-Test (Laboratory Of Mechanical Testing). Zona Manajemen ISSN 2087-6998. Fakultas Ekonomi Universitas Batam. Volume 8, Nomor 3, Desember 2016. Hal. 1-10.

Bangun, Wilson. (2012). Manajemen Sumber Daya Manusia. Penerbit Erlangga. Jakarta. Brahmasari, Ida Ayu dan Agus Suprayetno. 2008. Pengaruh Motivasi Kerja, Kepemimpinan dan Budaya Organisasi Terhadap Kepuasan Kerja Karyawan serta Dampaknya pada 
DIMENSI, VOL. 7, NO. $1: 100-120$

MARET 2018

ISSN: 2085-9996

Kinerja Perusahaan (Studi kasus pada PT. Pei Hai International Wiratama Indonesia). Jurnal Manajemen dan Kewirausahaan, Vol.10, No. 2, September 2008: 124-135

Darmayanti dan Ratnasari, Sri Langgeng. 2016. Pengaruh Gaya Kepemimpinan Dan Fasilitas Kerja Terhadap Kinerja Pegawai Pada Kantor Camat Batam Kota. Zona Manajemen ISSN 2087-6998. Fakultas Ekonomi Universitas Batam. Volume 8, Nomor 1, April 2016. Hal. 11-18

Devi, Eva Kris Diana. 2009. Analisis Pengaruh Kepuasan Kerja dan Motivasi Terhadap Kinerja Karyawan dengan Komitmen Organisasional sebagai Variabel Intervening (Studi pada Karyawan Outsourcing PT Semeru Karya Buana Semarang).

Djojo, Adji. (2012). Aplikasi Praktis SPSS dalam Penelitian. Penerbit Gava Media. Yogyakarta.

Efendi, Vivi Kusuma dan Ratnasari, Sri Langgeng. 2014. Pengaruh Kepemimpinan, Komunikasi, Dan Motivasi Kerja Terhadap Kinerja Guru SMA Di Kecamatan Batam Kota Batam. Zona Manajemen ISSN 2087-6998. Fakultas Ekonomi Universitas Batam. Volume 6, Nomor 3, Desember 2014. Hal. 1-13

Ghozali, H. Imam. (2013). Aplikasi Analisis Multivariate dengan Program IBM SPSS 21. Badan Penerbit Universitas Diponegoro. Semarang.

Handoko, T Hani. (2008). Manajemen Sumber Daya Manusia. BPFE. Yogyakarta.

Hasiholan, Leonardo Budi dkk. 2016. Pengaruh Gaya Kepemimpinan Transformasional, Kompensasi dan Komunikasi Terhadap Kinerja Karyawan dengan Kepuasan Kerja sebagai Variabel Mediasi pada Laundry Elephant King. Journal of Management, Volume 2 No.2.

Mangkunegara, Anwar.P. (2008). Manajemen Sumber Daya Manusia Perusahaan. Cetakan ke-8. Bandung: Rosda Karya.

Murty, W.A. dan Gunasti, H. 2012. Pengaruh Kompensasi, Motivasi dan Komitmen Organisasional Terhadap Kinerja Karyawan Bagian Akuntansi (Studi Kasus pada Perusahaan Manufaktur di Surabaya). The Indonesian Accounting Review Volume 2, No. 2, pages 215-228. 
Lilo, Christianto dan Ratnasari, Sri Langgeng. 2015. Pengaruh Gaya Kepemimpinan Dan Kompensasi Terhadap Kinerja Karyawan Pada PT. Supreme Nusapermai Development. Zona Manajerial. ISSN 2087-7331. Volume 7 Nomor 2, Agustus 2015. Hal. 50-69. Fakultas Ekonomi Universitas Batam

Murwanto, Didik dan Ratnasari, Sri Langgeng. 2016. Pengaruh Kompensasi dan Gaya Kepemimpinan Terhadap Motivasi Kerja Karyawan PT. Fast Precision Manufacturing Indonesia. Zona Manajerial. ISSN 2087-7331. Volume 8 Nomor 1, April 2016. Hal. 112. Fakultas Ekonomi Universitas Batam

Saputro, Andi dan Ratnasari, Sri Langgeng. 2014. Pengaruh Kepemimpinan dan Motivasi Kerja Terhadap Kinerja Karyawan PT. Giken Pricision Indonesia. Zona Manajerial ISSN 2087-7331. Volume 6 Nomor 3, Desember 2014. Fakultas Ekonomi Universitas Batam. Hal. 1-12.

Ratnawati, Intan dan Chaterina, M.T. 2012. Analisis Pengaruh Budaya Organisasi dan Kepuasan Kerja Terhadap Komitmen Organisasional dalam Meningkatkan Kinerja Karyawan (Studi pada PT. Sido Muncul Kaligawe Semarang). Jurnal Bisnis dan Ekonomi (JBE), Hal. 170-187, Vol. 19, No. 2 ISSN: 1412-3126.

Ratnasari, Sri Langgeng, Budiman Christiananta, dan Anis Eliyana. 202. Pengaruh Komitmen Organisasional dan Budaya Organisasi Terhadap Kepuasan serta Prestasi Kerja Dosen Tetap Yayasan Perguruan Tinggi Swasta di Provinsi Kepulauan Riau. Jurnal Akuntansi dan Manajemen (JAM) ISSN: 0853-1269, STIE YKPN Yogyakarta, Vol. 23, No.1, April 2012, TERAKREDITASI SK DIRJEN DIKTI NO.:64a/DIKTI/Kep./2010 Tanggal 1 Nopember 2010. Hal 51-60

Rivai, Veithzal. (2006). Manajemen Sumber Daya Manusia untuk Perusahaan: dari Teori ke Praktik. Edisi Pertama. Penerbit PT. Raja Grafindo Persada. Jakarta.

Sanusi, Anwar. (2011). Metodologi Penelitian Bisnis. Salemba Empat. Malang.

Sembiring, Masana. (2012). Budaya dan Kinerja Organisasi. Fokusmedia. Bandung. Sopiah. (2008). Perilaku Organisasional. Penerbit Andi. Yogyakarta.

Sugiono. (2006). Statistika Untuk Penelitian. Alfabeta. Bandung. 
Sugiono. (2012). Metode Penelitian Kuantitatif, Kualitatif, dan R\&D. Cetakan ke-15. Alfabeta. Bandung.

Sugiono. (2014). Metode Penelitian Kuantitatif, Kualitatif dan R\&D. Bandung: Alfabeta.

Thoha, Miftah. (2012). Peilaku Organisasi: Konsep Dasar dan Aplikasinya. Penerbit Rajawali Pers.

Tobing, Diana Sulianti, K.L. (2009). Pengaruh Komitmen Organisasional dan Kepuasan Kerja Terhadap Kinerja Karyawan PT. Perkebunan Nusantara III di Sumatera Utara. Jurnal Manajemen dan Kewirausahaan Vol. 11 No. 1, Maret 2009: 3-37.

Wasla, Elvina dan Ratnasari, Sri Langgeng. Pengaruh Gaya Kepemimpinan Dan Motivasi Terhadap Kinerja Karyawan PT. Citra Pembina Pengangkutan Industries Batam. EKSEKUTIF Jurnal Nasional Manajemen Bisnis Volume 13, Nomor 1, Juni 2016 ISSN: 1829-7501 Hal. 97-111

Umar, Husein. (2008). Desain Penelitian MSDM dan Perilaku Karyawan: Paradigma Posivistik dan Berbasis Pemecahan Masalah. Raja Grafindo Persada. Jakarta.

Wibisono, Dermawan. (2011). Manajemen Kinerja Korporasi dan Organisasi: Panduan Penyusunan Indikator. Penerbit Erlangga.

Wibowo, Agung Edy. (2012). Manajemen Pengembangan Sumber Daya Manusia. Pustaka Pelajar. Yogyakarta.

Wibowo. (2011). Manajemen Kinerja. Rajawali Pers. Jakarta. 